\title{
Complex structures in Brazilian Indigenous languages
}

\section{Estruturas complexas em línguas indígenas brasileiras}

Suzi Lima

University of Toronto. Toronto, Canadá

Tonjes Veenstra

Leibniz-Zentrum Allgemeine Sprachwissenschaft. Berlin, Alemanha

\section{INTRODUCTION}

The dossier "Complex structures in Brazilian indigenous languages" contributes to the ongoing upsurge of descriptions and analyses of complex sentence structures - a non-extensive list includes van Gijn et al. (2011, 2014), Storto (2012), Amaral et al. (2018), Zariquiey et al. (2019), among many others. Two or more non-serialized verbs characterize complex structures, that is, structures that highlight syntactic and semantic embedding. This dossier features five articles that explore different phenomena: clause chaining and switch reference, conditionals, conjunction and additive constructions, tail-head linkage, and anaphora and subordination. The majority of the articles resulted from research presented in a workshop with the same title as the dossier at the Associação Brasileira de Linguística (ABRALIN) 50 Meeting in Maceió, Alagoas, from May 02 to May 09, 2019. The description of the phenomena mentioned above is not only central for a better understanding of the languages featured in this dossier (Aikanã, Kwaza, Dâw, Gavião de Rondônia, Karitiana, Kuikuro) but also central for typological studies. Evidence from languages under-represented in the literature has proven to be highly revealing for linguistic theory in several cases. Three examples of this kind are the discussion of indexical shift in complex clauses in Amharic (Schlenker, 2003), Slave (Anand \& Nevins, 2004), among others, the semantics of logophoric pronouns in Ewe (Pearson, 2015), and the discovery of backward control, initially in Tsez (Polinsky \& Potsdam, 2002). Below we present a description of the papers presented in this dossier.

Franchetto (2021) describes counterfactual and non-counterfactual conditional constructions in Kuikuro (Upper Xingu Cariban language). Based on the analysis of texts available in the Kuikuro digital corpus and data from contextbased elicitation, she analyzes the morphosyntactic features of five different types of constructions that are used by Kuikuro speakers to encode counterfactual and non-counterfactual conditionals. One central contribution of the paper is the detailed discussion of the existence of a hypothetical mood morpheme in Kuikuro that is required in counterfactual constructions.

Lima, S., \& Veenstra, T. (2021). Complex structures in Brazilian Indigenous languages. Boletim do Museu Paraense Emílio Goeldi. Ciências Humanas, 16(3), e20210111. doi: 10.1590/2178-2547-BGOELDI-2021-0111

Autora de correspondência: Suzi Oliveira de Lima. University of Toronto. Department of Linguistics. Sidney Smith Hall, 4th floor 100 St. George St, Toronto, ON M5S 3G3 (suzi.lima@utoronto.ca).

Recebido em 15/11/2021

Aprovado em 16/11/2021

Responsabilidade editorial: Jimena Felipe Beltrão
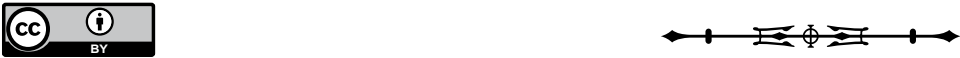
Moore (2021) describes conjunct and additive constructions in the Gavião language of Rondônia (Mondé branch, Tupian family). He presents a syntactic analysis of the distribution of the particle kî́ 'also, too, and' in three different types of constructions involving this particle in verb phrases and noun phrases and shows that kî́l may occur in additive constructions ('also, too'), in a sequence of additives ('and also') and in conjunction constructions ('and'). He also discusses the differences in the interpretation of additive and conjunction constructions by showing that the former is associated with a distributive interpretation and the latter with a collective interpretation.

Obert (2021) describes the formal and functional properties of tail-head linkage in Dâw (Naduhup family). She shows that the repetition of place references in Dâw narratives is a strategy used by its speakers for the establishment of event and participant coherence. Dâw narratives are discussed in light of the typological studies on tail-head linkage and Obert observes that while these constructions in Dâw share many formal and functional properties with other languages one characteristic feature of tail-head linkage in Dâw is that it is mostly restricted to locative adverbial clauses.

Storto (2021) describes anaphora and subordination in Karitiana (Arikém branch, Tupian family) by presenting the distribution of the medium-distance anaphor ta. She shows that this anaphoric element may find its antecedent in the matrix clause, in the same subordinate clause or between embedded clauses, and allows for a logophoric use, in which case the antecedent is not clearly mentioned in the immediate discourse.

Van der Voort (2021) describes clause chaining and switch-reference in Aikanã and Kwaza (isolate languages) and shows that both languages are characterized by medial clause chaining constructions that involve switch-reference systems. He documents the similarities that switch marking has in both languages (including dedicated morphological suffixes, and medial clauses inflected for person) as well as aspects in which they differ from each other, including the fact that in Kwaza but not in Aikanã switch reference markers may be used to signal a new topic, which is a phenomenon observed in other South American languages (van Gijn, 2012), and that the Kwaza system is anticipatory, unlike the Aikanã system.

In conclusion, the research reported on in this volume will help to advance the discussion in theoretical linguistics of the constructions mentioned above by means of featuring new data or new analyses of complex structures in languages that have been underrepresented in the literature so far.

\section{FUNDING}

This dossier is one of the scientific outputs of the project "Complex sentences in Brazilian native American languages: experimental and theoretical studies" (COSY) which was funded by the Deutsche Forschungsgemeinschaft (DFG, German Research Foundation) - grant 278211957, PI Uli Sauerland. Funding by the DFG - Project-ID 416591334 SFB 1412 for Veenstra's involvement is hereby also gratefully acknowledged.

\section{ACKNOWLEDGMENTS}

We would like to thank Jimena Felipe Beltrão and Hein van der Voort for their support in the organization of this special dossier. We also would like to thank all the authors and reviewers of this dossier.

\section{REFERENCES}

Amaral, L., Maia, M., Nevins, A., \& Roeper, T. (eds.). (2018). Recursion across domains. Cambridge University Press.

Anand, P., \& Nevins, A. (2004). Shifty operators in changing contexts. Semantics and Linguistic Theory, 14, 20-37. https://doi.org/10.3765/ salt.v14i0.2913

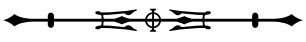


Franchetto, B. (2021). Counterfactual and non-counterfactual conditional constructions in Kuikuro (Upper Xingu Carib). Boletim do Museu Paraense Emílio Goeldi. Ciências Humanas, 16(3), e20200107. https://doi.org/10.1590/2178-2547-BGOELDI-2020-0107

Gijn, R. van. (2012). Switch-Attention (aka Switch-Reference) in South-American temporal clauses: Facilitating oral transmission. Linguistic Discovery, 10(1), 112-127. http://dx.doi.org/10.1349/PS1.1537-0852.A.407

Gijn, R. van, Haude, K., \& Muysken, P. (Eds.). (2011). Subordination in South American languages. John Benjamins. https://doi.org/10.1075/tsl.97

Gijn, R. van, Hammond, J., Matić, D., van Putten, S., \& Galucio V. (Eds.). (2014). Information structure and reference tracking in complex sentences. John Benjamins. https://doi.org/10.1075/tsl.105

Moore, D. (2021). Conjunction and additive constructions in the language of the Gavião of Rondônia. Boletim do Museu Paraense Emílio Goeldi. Ciências Humanas, 16(3), e20200105. https://doi.org/10.1590/2178-2547-BGOELDI-2020-0105

Obert, K. (2021). How to not lose the track: tail-head linkage as a mechanism for maintaining cohesion of spatial information in Dâw narratives. Boletim do Museu Paraense Emílio Goeldi. Ciências Humanas, 16(3), e20200100. https://doi.org/10.1590/2178-2547BGOELDI-2020-0100

Pearson, H. (2015). The interpretation of the logophoric pronoun in Ewe. Natural Language Semantics, 23(2), 77-118. https://doi.org/10.1007/ s11050-015-9112-1

Polinsky, M. \& Potsdam, E. (2002). Backward control. Linguistic Inquiry, 33(2), 245-282. https://www.jstor.org/stable/4179189

Schlenker, Ph. (2003). A plea for monsters. Linguistics and Philosophy, 26(1), 29-120. https://www.jstor.org/stable/25001879

Storto, L. (2012). Subordination in Karitiana. Amerindia, 35, 219-236.

Storto, L., \& Vivanco, K. (2021). Anaphora and subordination in Karitiana. Boletim do Museu Paraense Emílio Goeldi. Ciências Humanas, 16(3), e20200098. https://doi.org/10.1590/2178-2547-BGOELDI-2020-0098

Voort, H. van der. (2021). Clause chaining and switch-reference in Aikanã and Kwaza. Boletim do Museu Paraense Emílio Goeldi. Ciências Humanas, 16(3), e20210077. https://doi.org/10.1590/2178-2547-BGOELDI-2021-0077

Zariquiey, R., Shibatani, M., \& Fleck, D. W. (Eds.). (2019). Nominalization in languages of the Americas. John Benjamins. https://doi. org/10.1075/tsl.124

\section{AUTHORS' CONTRIBUTION}

All authors declared active participation during the stages of elaboration of the manuscript.

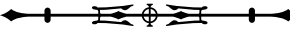

